\title{
PERILAKU KONSUMEN MUSLIM DI INDONESIA TERHADAP IBADAH UMROH: ANTARA 'UBUDIYAH DAN GAYA HIDUP
}

\author{
Fachrudin Fiqri Affandy \\ IAIN Fattahul Muluk Papua \\ E-mail: affandyjo@gmail.com
}

\begin{abstract}
ABSTRAK
Ibadah umrah merupakan salah satu ibadah di dalam Islam yang memiliki dua dimensi, yaitu dimensi duniawi dan dimensi akhirat. Penelitian ini mencoba untuk mengeksplor pola konsumsi masyarakat muslim dalam membelanjakan hartanya untuk memenuhi kebutuhan hidupnya, salah satunya ibadah umrah. Penelitian ini menggunakan jenis penelitian kualitatif dengan pendekatan kajian literatur terdahulu yang relevan, disesuaikan dengan fakta di lapangan dan kemudian disusun secara ilmiah dan dilanjutkan pada pembahasan. Hasil penelitian ini menunjukkan ibadah umrah memiliki dua dimensi, yaitu dimensi duniawi berupa gaya hidup dan dimensi akhirat yaitu ibadah. pola konsumsi masyarakat muslim dalam membelanjakan hartanya untuk ibadah umrah sejalan dengan pemenuhan kebutuhan dharuriyyat, hajiyyat, dan tahsiniyyat. Meskipun dalam kategori ibadah, umrah masih lekat dengan bisnis dan gaya hidup yang tidak mungkin dipisahkan antara keduanya.
\end{abstract}

Kata Kunci: Perilaku Konsumen, 'Ubudiyah, Gaya Hidup.

\section{ABSTRACT}

Pilgrim is a form of worship in Islam which has two dimensions, namely the worldly dimension and the afterlife dimension. This research tries to explore the consumption patterns of the Muslim community in spending their assets to meet their daily needs, one of which is pilgrims. The research uses qualitative method with relevant previous literature review approaches, adjusted to the field's facts and then scientifically compiled and discussed. The results showed that pilgrim has two dimensions, namely the worldly dimension in the form of lifestyle and the afterlife dimension, namely worship. The Muslim community's consumption pattern in spending their assets for pilgrim is in line with fulfilling the needs of dharuriyyat, hajiyyat and tahsiniyyat. Even though it is in the worship category, pilgrim is still closely related to a business and lifestyle that cannot be defeated.

Keywords: Consumer Behavior, 'Ubudiyah, Lifestyle 


\section{PENDAHULUAN}

Islam adalah sebagai agama risalah samawi yang universal, datang untuk menangani kehidupan manusia dalam berbagai aspek, baik dalam aspek spiritual, maupun aspek material. Artinya islam tidak hanya berbicara mengenai akidah, akan tetapi juga mencakup politik, social, budaya, dan perekonomian yang ditujukan untuk seluruh umat manusia. Inilah yang diungkapkan dengan istilah, islam adalah Ad-Diin yang mencakup masalah akidah dan syariah. Sebagai agama yang sempurna, islam juga telah mengatur sistem dan konsep dalam berekonomi. Yang tentunya menjadi pedoman umat Islam dalam menjalankannya. (Rozalinda, 2015).

Ajaran, sistem dan konsep ekonomi dalam Islam sangat menarik untuk dibahas karena selalu berkaitan dengan kehidupan masyarakat pada umumnya,dan khususnya umat muslim. Kegiatan perekonomian merupakan alur kehidupan bagi semua manusia untuk memenuhi kebutuhan hidupnya baik dalam individu, maupun sosial. Kegiatan berekonomi tidak hanya berbicara mengenai harga, pasar, pemasaran, manajemen dan lain sebagianya. Akan tetapi produksi, distribusi serta konsumsi menjadi beberapa kajian yang menarik untuk dikaji secara mendalam tentunya dalam perspektif ekonomi Islam.salah satunya konsumsi. (Rozalinda, 2015).

Di dalam teori konsumsi ekonomi, kepuasan sesorang dalam mengkonsumsi suatu barang dinamakan utility atau nilai guna. Jika kepuasan terhadap suatu benda atau jasa yang digunakan semakin tinggi, maka semkin tinggi pula nilai gunanya. Begitupun sebaliknya. Dalam konvensional kepuasan hanya dilihatdari pencapaian terpenuhinya kebutuhan yang sifatnya fisik. Dalam Islam sendiri kepuasan dikenal dengan sebutan Maslahah dengan pengertian terpenuhinya kebutuhan fisik dan kebutuhan spiritual. Dalam memenuhi kemaslahatannya, manusia harus mempertimbangkan cara mendapatkannya tentunya tidak bersikap israf (berlebihan) dan tabzir (sia-sia). (Rozalinda, 2015).

Erat kaitannya dengan konsumsi masyarakat muslim, kegiatan wisata religi menjadi salah satu kegiatan konsumsi masyarakat untuk mendapatkan kepuasan beribadah yang berimplikasi terhadap kepuasan spiritual. Salah satu contohnya, ibadah Umroh, dilihat dari segi bahasa, 'Umroh itu sendiri artinya meramaikan, yaitu meramaikan tempat suci Makkah, yang disitu terletak Masjidil Haram dan di dalamnya terdapat bangunan suci umat muslim yaitu Ka'bah. Dalam konteks ibadah, umroh tidak sekedar meramaikan, melainkan kita dituntut untuk mengambil manfaatnya dari 'Umroh tersebut. (Madjid, 2008).

Indonesia menjadi salah satu Negara dengan jumlah jamaah 'umroh yang setiap tahunnya mengalami peningkatan. Hal ini disampaikan oleh Humas Kemenko PMK yang mendaptkan data dari Kemenag bahwa jumlah jamaah 'umroh Indonesia dala lima tahun terakhir mengalami peningkatan sejak tahun 
2014-2015 berjumlah 649.000 jama'ah, meningkat di tahun 2015-2016 sebanyak 677.509 jama'ah, naik lagi di 2016-2017 yaitu sebesar 876.246 jama'ah, kemudian melonjak signifikan di tahun 2017-2018 sebanyak 1.005.336 dan mengalami penurunan di tahun 2018-2019 menjadi 974.650 jama'ah. (www.KemenkoPMK.go.id, 2020).

Fenomena yang terjadi pada saat ini khususnya wisata religi ('Umroh) yang dilakukan oleh para public figure, khususnya masyarakat muslim di Indonesia lebih terkesan kepada kegiatan wisata dibandingkan dengan kegiatan spiritual. Mengingat 'Umrah salah satu ibadah yang memerlukan biaya yang cukup lumayan banyak dan waktu yang begitu singkat dalam menjalankannya. Tentunya dibutuhkan persiapan baik finansial, mental, serta spiritual. Dengan banyaknya biaya dan persiapan, tentunya tujuan utama dari pada Umrah tak lain hanya untuk mendapatkan kepuasan secara spiritual dan Ridho dari Allah SWT. 'Umroh menjadi salah satu ibadah yang berdampingan dengan kegiatan wisata, salah satunya dengan mengunjungi makam-makam (ziarah) para 'Ulama' bahkan makam Rasulullah SAW. Hal ini menjadikan kegiatan wisata religi (Umrah) semakin menarik untuk dikaji secara mendalam, apakah tujuan konsumsi dalam ibadah seperti ini merupakan kebutuhan ibadah atau hanya menjadi sebuah gaya hidup.

Artikel ini mencoba melihat ibadah 'umroh melalui perspektif perilaku konsumen muslim dalam membelanjakan hartanya. Selain itu untuk melihat esensi dari ibadah 'umroh yang mana masuk dalam kategori gaya hidup atau menjadi sarana ibadah yang bersifat 'ubudiyah (Kebaktian/ketaaatan) hamba-Nya terhadap Allah SWT.

\section{KAJIAN LITERATUR \\ Perilaku Konsumen}

Para ahli berpendapat mengenai definisi Perilaku Konsumen, sebagai berikut ; Gerald Zaldman dan Melanie Wallendorf di dalam Rini Dwi Astuti menjelaskan bahwa : Perilaku konsumen adalah tindakan-tindakan, proses, dan hubungan sosial yang dilakukan individu, kelompok, dan organisasi dalam mendapatkan, menggunakan suatu produk atau lainnya sebagai suatu akibat dari pengalamannya dengan produk, pelayanan, dan sumber-sumber lainya. Menurut Solomon di dalam Rini Dwi Astuti, Studi Perilaku Konsumen merupakan proses ketika individu atau kelompok menyeleksi, membeli, menggunakan atau membuang produk, pelayanan, ide dan pengalaman untuk memuaskan kebutuhannya. (Astuti, 2012).

Faktor-faktor yang mempengaruhi perilaku konsumen seseorang dalam mengambil keputusan pembelian sebuah barang atau jasa, menurut Kotler dan 
Amstrong di dalam Ayunda, diantara sebagia berikut : (Ayunda, Mutmainnah, Huda, 2019).

1. Faktor Budaya, terdiri dari budaya, subbudaya, dan kelas sosial

2. Faktor Sosial, terdiri dari keluarga, peran, kelompok referensi, dan status

3. Faktor Pribadi, terdiri dari usia, pendidikan, pekerjaan, dan gaya hidup

4. Faktor Psikologis, terdiri dari motivasi, pembelajaran, dan memori.

Pada kenyataanya, kepuasan dan perilaku konsumen dipengaruhi oleh hak -hak sebagai berikut:

1. Nilai guna barang dan jasa yang dikonsumsi. Kemampuan barang dan jasa untuk memuaskan kebutuhan dan keinginan konsumen

2. Kemampuan untuk mendapatkan barang dan jasa. Daya beli dari income konsumen dan ketersediaan barang dipasar.

3. Kecenderungan konsumen dalam menentukan pilihan konsumsi menyangkut pengalaman masa lalu, budaya, selera, serta nilainilai yang dianut seperti agama, adat istiadat. (Mulyono, 2013).

Pada tingkatan praktis, perilaku ekonomi (Economic Behaviour) sangat ditentukan oleh tingkat atau keimanan sesorang atau kelompok orang yang kemudian mebentuk kecenderungan perilaku konsumsi di pasar. Seorang muslim dalam penggunaan penghasilannya memiliki 2 sisi, yaitu untuk kebutuhan sendiri dan keluarganya dan sebagainya lagi untuk dibelanjakan di jalan Allah SWT. (Mulyono, 2013).

\section{Perilaku Konsumtif}

Perilaku konsumtif adalah perbuatan seseorang dalam mengkonsumsi suatu barang atau jasa, tanpa menggunakan pertimbangan akal dan pertimbangan kebutuhan. Menurut Trianingsih di dalam Ayunda, pada umumnya individu mempunyai sifat konsumtif karena dipengaruhi oleh iklan, hegemoni, serta keinginan mengikuti trend atau gaya hidup untuk mendapatkan pengakuan atas dirinya sendiri. (Ayunda, Mutmainnah, Huda, 2019).

Sementara menurut Sumartono di dalam Ayunda, terdapat delapan indikator perilaku konsumtif, diantaranya :

1. Membeli produk karena ingin mendapatkan hadiah

2. Membeli produk karena kemasan yang menarik

3. Membeli produk karena eksistensi diri dan gengsi

4. Membeli produk atas pertimbangan bukan manfaat

5. Membeli produk untuk menjaga status sosial 
6. Memakai produk karena unsur konformitas terhadap model yang mengiklankan

7. Adanya penilaian jika membeli produk mahal akan menambah rasa percaya diri

8. Mencoba dua produk atau lebigh dalam satu waktu, namun produk pertama belum habis manfaatnya.

\section{Gaya Hidup (Life Style)}

Gaya hidup dapat di artikan sebagai segala sesuatu yang memiliki karakteristik, kekhususan, dan tata cara dalam kehidupan bermasyarakat. Menurut Pilliang, gaya hidup dapat dipahami sebagai sebuah karakeristik. Seseorang secara kasat mata, yang menandai sistem nilai, serta sikap terhadap diri sendiri dan lingkungannya. (Hardanti, dan Sudarwati, 2015). Gaya hidup dapat menjadi sebuah identitas seseorang dalam pergaulan dengan lingkungan sekitarnya.

Dalam sudut pandang ekonomi, gaya hidup sebagai bukti seseorang dalam mengalokasikan pendapatannya untuk memilih satu alternatif pada jenis produk yang ada. (Suryani, 2008). Gaya hidup menunjukkan identitas seseorang dalam pergaulannya. Tidak hanya itu, gaya hidup dapat mempengaruhi seseorang dalam mengambil keputusan berkaitan dengan prinsip konsumsinya.

\section{Gaya Hidup Dalam Islam}

Dalam pandangan islam, memanfaatkan waktu, uang, kesempatan telah diatur di dalam Al-Qur'an dan Hadits. Islam tentunya memiliki indikator tentang gaya hidup menurut perspektif Islam, diantaranya : (Idri, 2015).

1. Menjalankan Kehidupan (Sederhana)

2. Memilih Produk Jasa

3. Menjaga Kebersihan

4. Memanfaatkan Waktu

\section{Perilaku Konsumen Muslim}

Perilaku konsumen pada dasarnya adalah untuk memenuhi kebutuhan dan keinginan. Kebutuhan adalah sesuatu yang harus dipenuhi untuk mempertahankan keberlangsungan hidup seseorang. Sedangkan keinginan berkaitan dengan hasrat yang belum tentu akan mendatangkan manfaat atas produk yang dikonsumsi. Terkait dengan hal tersebut, perilaku konsumen muslim harus dilandasi atas nilai syariah yang terkandung di dalam Al-Qur'an dan Hadits. Semisal tidak berlebihan dalam mengkonsumsi.

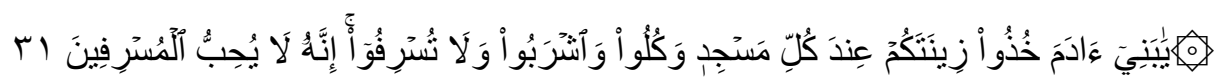


Terjemahnya: Hai anak Adam, pakailah pakaianmu yang indah di setiap (memasuki) masjid, makan dan minumlah, dan janganlah berlebihlebihan. Sesungguhnya Allah tidak menyukai orang-orang yang berlebihan (QS. Al-A'raf: 31).

Dalam mempelajari perilaku konsumen muslim, tidak terlepas dari menggunakan pendekatan Akhlaq. Abu Yazid al-Bustami dan Ibnu 'Arobi membagi menjadi tiga yaitu: Qonaah, Adil, dan Ihsan. (Muflih, 2006).

Kebutuhan menurut Imam Asy-Syatibi, kebutuhan adalah pemilikan atau kekuatan barang dan jasa yang mengandung elemen-elemen dasar dan tujuan kehidupan umat. Terbagi menjadi tiga yaitu, kebutuhan (daruriyah), pelengkap (hajiyah), dan perbaikan (Tashniyah). (Muhammad, 2004).

Dalam ilmu ekonomi Islam, anugerah Allah SWT adalah milik semua manusia. Apa yang telah dianugerahkan kepada manusia tentunya harus dimanfaatkan secara baik. Bentuk pemanfaatan secara baik dan optimal menjadi bentuk ketaatan seorang hamba kepada sang pencipta. (Suprayitno: 2005).

Adapun prinsip konsumsi dalam Ekonomi Islam diantaranya:

1. Prinsip Keadilan

2. Prinsip Kebersihan

3. Prinsip Kesederhanaan

4. Prinsip Murah Hati

5. Prinsip Moralitas

\section{METODOLOGI PENELITIAN}

Penelitian ini berjenis kualitatif dengan menggunakan pendekatan kualitatif deskriptif. Metode yang digunakan dalam penelitian ini menggunakan metode analisis berdasarkan kajian kepustakaan. Studi analisis dalam penelitian ini studi komparasi hasil penelitian terdahulu yang relevan dengan pembahasan. Data primer yang sudah terkumpul akan disusun sesuai dengan kaidah penulisan sehingga mempermudah untuk menganalisis.

Penulis menggunakan metode ini untuk mengkaji perilaku konsumsi masyarkat muslim dalam hal pelaksanaan indah umrah secara teori maupun empiris berlandaskan perspektif konsumsi dalam Islam. Metode pengumpulan data dalam kajian pustaka meliputi mempelajari literatur terdahulu yang relevan dengan penelitian. Metode analisis yang digunakan adalah teknik analisis data desriptif kualitatif data-data yang diperoleh dari tinjauan literature yang kemudian disusun sesuai dengan fakta yang ada untuk dilanjutkan pada pembahasan. 


\section{HASIL DAN PEMBAHASAN}

Manusia pada umumnya akan mendapatkan puncak dari sebuah kejenuhan dalam beraktivitas, baik itu bekerja maupun bersosialisasi dengan masyarakat lainnya atau bahkan ketika mendapat kesukaran dalam hidup. Hal ini yang sering dirasakan oleh umat muslim, termasuk kita yang ada di Indonesia. Salah satu cara untuk menghilangkan kejenuhan tersebut dengan jalan melakukan kegiatan wisata, yang bertujuan untk memperbaiki kembali psikologi yang telah menurun.

Diantaranya yang dapat kita lakukan dengan melakukan wisata religi. Wisata religi memiliki dua nilai dalam implementasinya, yang pertama bernilai ibadah dan bernilai ekonomis. Bernilai ibadah diartikan dengan melakukan wisata religi (ziaroh, haji, umroh, dan lain sebagainya) memberikan dampak terhadap jiwa spiritual setiap individu. Manusia akan selalu ingat tempat terakhirnya kelak setelah menjalani kehidupan di dunia. Berkaitan dengan nilai ekonomis, tentunya memerlukan pengorbanan yang tidak sedikit dalam mewujudkannya. Salah satunya ibadah Umrah. Ibadah yang dilaksanakan dengan mengeluarkan sejumlah uang untuk dapat melaksanakannya.

Seiring dengan berkembangya zaman dan teknologi yang semakin maju, telah banyak berdiri biro jasa perjalanan, baik yang sifatnya murni menawarkan wisata dan biro perjalanan yang mengkombinasikan antara ibadah dan wisata atau lazim disebut dengan wisata religi. Tentunya pangsa pasar dari kedua jenis biro ini berbeda, jika penawaran yang murni menjual paket wisata lebih mengarah kepada konsumen secara luas, sedangkan pada biro perjalanan yang mengkombinasikan antara wisata dan ibadah mengarah kepada konsumen yang ingin mendapatkan dua kepuasan, yakni kepuasan dalam beribadah dan kepuasan terhadap jasmani mereka.

Fenomena inilah yang sedang terjadi di Indonesia, banyak masyarakat yang memiliki dana lebih untuk menggunakan dan mengkonsumsi pendapatannya untuk menggunakan dan mengkonsumsi pendapatannya untuk melakukan kegiatan wisata sekaligus beribadah. Pada dasarnya tidak ada hal yang perlu dikhawatirkan atau bahkan dilarang pada hal semacam ini. Akan tetapi perlu dipikirkan secara bijak. Salah satu contoh ibadah yang sering dilakukan adalah Umrah. ibadah Umrah atau haji adalah ibadah yang diperintahkan oleh Allah SWT dan Rasulnya. Ibadah ini dimulai sejak nabi adam as menginjakkan kakinya di muka bumi dan membangun Ka'bah (Baitullah).

Orang-orang berhaji dan berumroh adalah tamu Allah SWT. Setiap individu melakukan pengorbanan yang tidak sedikit. Allah SWT akan mengabulkan apa yang mereka minta. Tentunya ibadah haji dan Umrah merupakan puncak dari kesempurnaan Islam, seperti Firman Allah SWT, QS. AlBaqoroh: 196. 


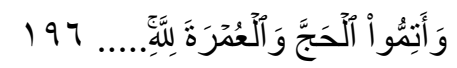

\title{
Terjemahnya: Dan sempurnakanlah ibadah haji dan umrah karena
}

\author{
Allah....(QS. Al-Baqoroh:196)
}

Perilaku konsumsi pada masyarakat muslim seperti ini tidak ada yang menyalahkan, akan tetapi perlu diperhatikan dan dibedakan antara kegiatan yang sifatnya spiritual dan kegiatan yang sifatnya jasmani. Semuanya memiliki pendangan yang berbeda-beda mengenai hal tersebut. Esensi dari kegiatan ibadah adalah ingin mendapatkan kepuasan yang sifatnya melalui spiritualitas dan tentunya mendapatkan ridho dari Allah SWT. Diawali dengan niat yang tulus agar keinginan yang dicapai melalui ibadah mendapatkan ridho dari Allah SWT. Perilaku konsumsi harus memperhatikan antara kebutuhan dan keinginan. Kebutuhan menjadi sebuah hal yang harus dipenuhi terlebih dahulu sebelum memenuhi keinginan.

Terkait pelaksanaan wisata religi yang ada, perlu dipertimbangkan dalam melakukan pengeluaran. Jika dilakukan atas dasar ibadah, tentunya akan menjadi sebuah kebaikan bagi setiap individu yang menjalankan. Akan tetapi jika didasari Trend, atau gaya hidup (Life Style) dalam melakukan kegiatan wisata religi, kiranya perlu dipikirkan secara cermat. Mengingat pengorbanan yang dikeluarkan dalam hal ini keuangan tidak sedikit dan hasil yang didapatkan tidak sama dengan tujuan ibadah secara murni.

Beberapa penelitian yang relevan dengan penelitian ini pernah dilakukan oleh Sucipto. Hasil dari penelitian tersebut menunjukkan ibadah 'umroh yang dilakukan oleh warga kelas menengah Kota Jambi menjadi bagian dari infrastruktur religiusitas yang memiliki maslahah dan good interest dalam gaya hidup mereka. Ibadah umrah memiliki dua dimensi, yaitu dimensi dunia (gaya hidup) dan dimensi akhirat (aspek spiritual). (Sucipto, 2013).

Penelitian yang dilakukan oleh Subkhani menunjukkan hasil ibadah umrah telah menjadi turisme spiritual yang menjadi nilai tambah bagi biro perjalanan ibadah haji dan umroh untuk membentuk strategi dalam menarik jama'ah. Namun ibadah umrah juga memiliki dimensi spiritual yang tidak terpisahkan yaitu nilai ibadah. (Dewi, 2017).

Beberapa penelitian di atas mengungkap ibadah umroh memiliki dua dimensi yang tidak dapat dipisahkan. Dimensi duniawi meliputi ekonomi, individu, sosial, gaya hidup, hingga turisme spiriual. Dimensi akhirat meliputi, keagamaan, kesalehan, dan ketaatan beribadah.

Penelitian ini mencoba untuk mengeksplor dari sisi perilaku konsumen muslim dalam membelanjakan hartanya untuk mendapatkan kepuasan dan ketenangan baik secara jasmani dan rohani, yaitu ibadah umrah. Perilaku Konsumen muslim dalam hal ibadah 'umroh tentunya tidak dapat dilihat dari satu 
sudut pandang ekonomi, melainkan sudut pandang agama. Dari sudut pandang ekonomi, ibadah umrah merupakan ibadah yang memerlukan pengorbanan biaya yang tidak sedikit untuk melaksanakannya. Di mulai dari persiapan, akomodasi, hingga keperluan di Mekkah sampai dengan kembali setelah melaksanakan ibadah 'umroh. Disisi lain, ibadah 'umroh menjadi salah satu bentuk ketaatan seoarang hamba terhadap sang pencipta untuk dapat berkunjung ke Baitullah.

Dari sudut pandang ekonomi, dapat dikaitkan dengan pola konsumsi konsumen muslim dalam hal melakukan ibadah uumrah. Merujuk pada urgensi kebutuhan dalam konsumsi Maqashid Syariah Imam Asy-Syatibi, , ibadah 'umroh masuk dalam kategori kebutuhan untuk memperbaiki diri (Tahsiniyat). Ibadah 'umroh menjadi tingkatan terkahir kebutuhan yang harus dipenuhi apabila memiliki kelebihan rezeki oleh setiap umat muslim. Pola konsumsi yang dilakukan oleh masyarakat muslim sejatinya telah mendahulukan kebutuhan dharuriyyah dan hajiiyah, sehingga perilaku konsumsi yang dilakukan tidak menyalahi aturan agama, meskipun di dalam nya terkandung unsur duniawi berupa ekonomi dan gaya hidup.

\section{KESIMPULAN}

Pelaksanaan Ibadah Umrah memiliki dua dimensi, yaitu dimensi ibadah dan dimensi ekonomi. Dimensi ekonomi meliputi perilaku konsumen muslim dalam membelanjakan hartanya harus sejalan dengan prinsip pemenuhan kebutuhan menurut Imam Asy-Syatibi diantaranya mendahulukan kebutuhan Dharuriyyat, Hajiiyyat, dan yang terakhir Tahsiniyyat (ibadah umrah). Namun harus diakui, dimensi duniawi seperti ekonomi dan gaya hidup masih menempel pada ibadah Umrah yang memiliki nilai lebih dibandingkan dengan ibadah lainnya.

\section{SARAN}

Dalam membelanjakan harta perlu dipertimbangkan secara cermat dengan mengunakan akal sebagai pembeda antara murni sebagai kebutuhan spiritual, atau mengikuti Trend atau biasa disebut sebagai gaya hidup (Life Style). Skala prioritas kebutuhan Imam Asy-Syatibi sangat tepat dijadikan pedoman setiap muslim untuk senantiasa membelanjakan haratanya sesuai dengan rantai kebutuhan dalam Islam.

Penelitian ini masih bersifat umum, mengingat menggunakan kajian kepustakaan tentunya masih memiliki banyak kekurangan di dalamnya. Saran untuk peneliti selanjutnya untuk dapat mengeksplor makan konsumsi dalam perspektif Ekonomi Islam dan Relevansinya dalam kehidupan sehari-sehari. 


\section{DAFTAR PUSTAKA}

Astuti Dwi Rini, Agustina Shinta, Riyanti Isaskar, (2012), Ilmu Perilaku Konsumen, Cet. Ke-1, Malang: UB Press.

Ayunda Anju, Mutmainnah Lu'liyatul, Huda Nurul, (2019), Analisis Terhadap

Perilaku Konsumen Produk Fashion Muslim,Jurnal of Economics and Business Aseanomics (AJEBA) Vol. 3. No. 2.

Bahar, (2007), Manfaat Haji dan Umroh Untuk Kesehatan, Cet. Ke-1, Jakarta: Qultum Media.

Dewi Kusuma Subkhani, (2017), Trend Wisata Umrah: Antara Meneladani Sunnah dan Turisme Spiritual, Vol. 26, No. 2.

Hardianti Yulia, Lina Sudarwati, (2015), Etos Kerja dan Gaya Hidup Pada Masyarakat SLUM AREA, Jurnal Psikologi, Vol. 3, No. 1.

Idri, (2015), Hadis Ekonomi Dalam Perspektif Hadis Nabi Edisi Pertama, Jakarta: Kencana.

Madjid Nurcholis, (2008), Perjalanan Religius 'Umroh dan Haji, Cet. Ke-3, (Jakarta Timur: Paramadina.

Muhammad, (2006), Perilaku Konsumen Dalam Perspektif Islam, (Eds) ke-1, Jakarta: RajaGrafindo.

-,(2004), Ekonomi Mikro dalam Perspektif Islam, Cet. Ke-1, Yogyakarta: BPFE.

Mulyono Sugeng, (2013), Teori Perilaku Konsumen dalam Perspektif Ilmu Ekonomi Islam, Jurnal Penelitian Vol. 2 No. 1.

Rozalinda, (2015), Ekonomi Islam: Teori dan Aplikasi pada Aktivitas Ekonomi, (Eds) ke-1, Cet. Ke-2, Jakarta: RajaGrafindo.

Sucipto, (2013), Umrah Sebagai Gaya Hidup, Eksistensi Diri dan Komoditas Industri: Menyaksikan Perubahan Keagamaan Warga Kota, Jurnal Kontekstualita, Vol. 28, No. 1.

Suprayitno Eko, (2005), Ekonomi Islam, Yogyakarta: Graha Ilmu.

Suryani Tatik, (2008), Perilaku Konsumen Implikasi Pada Strategi Pemasaran, Yogyakarta: Graha Ilmu. 